\title{
THE IMPORTANCE AND DEVELOPMENT OF COURTYARDS IN CENTRAL ASIAN ARCHITECTURE
}

\author{
Mahmudov Nasimbek \\ PhD applicant of Fergana polytechnic \\ institute
}

\author{
Tursunova Dilnoza \\ PhD applicant Fergana polytechnic \\ institute
}

Article DOI: https://doi.org/10.36713/epra4447

\begin{abstract}
ANNOTATION
This article describes the history, importance, differences, development, and role of courtyards in Central Asian architecture. Restoration and repair of courtyards in Central Asia, the establishment of defensive zones in all historical monuments, as well as the formation of a system of tourist routes remain a difficult task for today's architecture.
\end{abstract}

KEYWORDS: Traditional architecture, courtyard, opposite porches, summer room, teracce.

\section{INTRODUCTION}

In the context of Central Asia, it is clear that the courtyard is a key element of housing construction. This can also be seen in the word "yard" instead of the word "home". Housing is divided into external and internal parts (external and internal or "Berun and Darun"). In Berun, the host is engaged in manual labor, receives guests, there is a hotel, warehouse, stables. In Darun, the family spends their whole lives. The type of housing depends on the location conditions. The house is made up of many components and with all its facilities it forms a whole ensemble, which is the basis of the abundance of options. The appearance of housing depends on a whole set of different social, historical, ethnic, natural-climatic factors. The characteristics of each of them, the changes in them lead to changes in the structure of housing. Historical conditions play an important role in the formation of housing types. The division of the feudal lords led to the emergence of local cultural hotbeds and various architectural traditions.[1]

\section{RESEARCH METHODOLOGY}

First Below we give an overview of the types of Uzbek housing.

The Bukhara apartment house is divided into summer rooms facing north and winter rooms facing south or west. Such a design also applies to the outdoor courtyard. Depending on the material supply of the host, several more rooms will be added, which will be divided into western and eastern rooms depending on the direction. A high, open, brick terrace is widely used in the Bukhara house. The tall, multi-columned porch sometimes took on the appearance of a summer room. Another distinctive feature of Bukhara houses is that the courtyard structure is in the form of stairs. The yard is in the form of a well, the highest point is at the height of the summer room, and the device is usually leveled accordingly. Such a composite structure provides the desired climatic regime, increases airflow, improve air exchange and ventilation.[1]

The compositional basis of the Khiva house consists of a rectangular courtyard and opposite porches. There is a high porch facing north, behind it there is a summer room - a palace, next to which 
there are other living rooms. In front of the porch is a low farm reverse porch.

A distinctive feature of the planning of houses in the Ferghana Valley is that the central room is a symmetrical combination of two rooms in contact with the palace, the facade of the warehouse consists of high-rise window columns and a small porch built along the roof. The central room is spacious and it was used not only as a front room but also as a common room for everyone. This room is often built facing south. Distinctive details of the facade are raised shelves, grille walls.

Shakhrisabz houses are an independent type in terms of their architectural structure. The starting element of the composition is a room with a singlecolumn porch. If there are two rooms in the house, a porch is built between them. In multi-room homes, the main group of rooms is built around the perimeter of the yard.[2]

For traditional residential buildings in Tashkent, a series of rooms with one or two columns and a number of terraces is typical. The room, which is considered the "Fergana" method, also has terraces and terraces with many columns.

The planned solution of the Samarkand house is to build one or two rooms with a narrow front room. Uzbek houses consist of two components: volume and spatial components. There are several compositional solution options for the terrace. In the residential complexes of Central Asian cities (Khiva) were built large courtyards with two terraces, the axes of which were oriented from south to north, the windows of the main summer rooms were the windows of winter rooms facing north and south. The porch in front of the summer room was two stories high, the rest one floor. The large terrace catches a stream of cold air during the hot summer months and directs it downwards. A low porch was built in front, as a result of which part of the courtyard was covered by the roof of the porch.[2]

In Bukhara, there is an terrace or a half terrace type. In multi-room houses, the courtyard surrounded by appliances forms a unique composition with it.

A special feature of the loggia is the ceiling, which is common in Karshi and Shakhrisabz. Such ceilings are covered with a double sloping roof, which occupies the entire width of the roof and provides elliptical ventilation.

The indoor courtyard type is common and comes in a variety of shapes. The indoor courtyard type in Margilan is interesting in its structure, occupying the space between the winter indoor courtyard and the indoor terrace. The use of traditional courtyards not only in traditional residential architecture, but also in public buildings, and the use of courtyards of architectural complexes is a distinctive feature of Central Asian architecture.

Courtyards have been used in public buildings since time immemorial. The first compositions used in the architecture of Central Asian public buildings are associated with temples. The first courtyard compositions in public buildings can be found in the example of the fire room in "Jarkoton" (XV-IX centuries BC). There were small apartments, fireplace-shaped houses built in the courtyard covered with raw bricks. In the "Kuykirilghan" Tower (2nd century BC, 4th century $\mathrm{AD})$ in the center of the courtyard, surrounded by a round wall, an observatory-like central structure defined the composition of the building.[3]

It is known that in the architecture of public buildings in Central Asia, courtyards had a clear compositional form in the II and II centuries BC. The method of building a regular courtyard in the Fayoztepa temple and the central composition of the "Kuykirilghan" Tower can be seen to have continued in medieval architecture. The further development of courtyard traditions is associated with the Islamic period. According to N.Brunov, it is common for Islamic architecture to have a courtyard with access from all the interior rooms, and these rooms are always connected to the spatial area of the courtyard. It is this feature that unites oriental architectural monuments. Although the first courtyard mosques appeared in Arabia, its various forms were formed in Central Asia. The first courtyard mosques built in Central Asia are still included in the "Arab" style. Our research acknowledges that the architecture of courtyard mosques in Central Asia has been greatly influenced by local fire worshipers, Buddhist temples. For example, the gates of mosques, miyansaray, the sides and fronts are due to the "chartak" architecture, while the galleries are due to the influence of Buddhist "devon" type courtyards. W. W. Barthold first noted that madrassas originated in the east of the Islamic world, in Central Asia, and that it was built on the model of a Buddhist temple. It is also home to madrassas in Balkh Province (Afghanistan), which was famous for Buddhism before the Arab conquest. As E.Herfeld points out, the construction of these new buildings was based on the history of residential, caravanserai and other buildings in Central Asia, using a four-porch courtyard - the Iranian system. According to another theory, the successors of the madrasas were the first medieval Central Asian palaces, which had four entrances and a domed room in the center, later the entrances were converted into a porch, the room in the middle into a courtyard.[3]

Along with the Buddhist temple, the madrassas have common similarities and are limited to building rooms around the courtyard. To protect people, animals, and cargo, they began to build 
caravanserais along caravan routes. They are surrounded by walls (usually with two rows of walls), in which towers and half-towers are built, surrounded by a compact rectangular arranged courtyard with many rooms. In modern architecture, courtyard traditions have declined somewhat since the early twentieth century, but until the 1960s, key aspects of architectural heritage were observed.

\section{CONCLUSION}

The As a result of the former Union's interference in the development of agriculture and the arts, the architectural heritage was rejected and the original roots of traditional courtyard architecture were overlooked. The current political and economic processes in the country, a new approach to private, public and state property require a rapid identification of ways of architectural development of historic cities and villages in the new conditions. A new concept is currently being proposed. It is aimed at solving a number of historical, urban and typological problems, as well as radically improving the social conditions of life, improving living conditions, increasing housing, utilities, transport, trade and other services. Its important aspects are the restoration and repair of architectural monuments, the establishment of defensive zones in all historical sites, as well as the formation of a system of tourist routes. The height of the buildings adjacent to the architectural monuments in the protection zones is 1-2 storeys, where the building system is very dense, which is an example of the traditional architectural variable construction method. By focusing on the courtyard structure, very good microclimatic results can be achieved by lowering the north and east sides of the building and raising the rest, which can lead to very impressive results in modern architecture.

\section{REFERENCES}

1. Salimov, D. Tursunova, "The problems of preservation and use of architectural monuments of the fergana region," IJMR, vol. 6, iss. 2, pp. 263-266, February 2020.

2. D. Tursunova, N.Mahmudov, Farg'ona vodiysi choyxonalarining arxitekturaviy kompozitsion yechimi, 2nd ed., vol. 1. Qo'qon, 2020, pp.117-121.

3. J.D. Axmedov and S.R. Qosimov, "Uy joy binolari qurilishida tejamkorlik va iqtisodiy ustuvorlik masalalari," FarPI Ilmiy texnika jurnali, vol. 23, Farg'ona, 2019, pp. 196199. 